\title{
Evaluation of different sources of organics on fertility status of soil and nutrient uptake of sweet corn [Zea mays (L.) saccharata]
}

\author{
B.R. WAGHMODE*, S.V. SONAWANE ${ }^{1}$ AND D.S. TAJANE ${ }^{1}$ \\ Department of Agronomy, College of Agriculture, University of Agricultural Sciences, \\ DHARWAD (KARNATAKA) INDIA(Email : waghmodebaburao@gmail.com)
}

\begin{abstract}
A field experiment was carried out during Kharif 2009-10 at Main Agricultural Research Station, University of Agricultural Sciences, Dharwad to find out the influence of organic nutrients on nutrient uptake and fertility status of soil. The experiment has twenty four treatment combinations comprising of organic manures mainly green leaf manure (GLM), enriched compost, FYM and vermicompost and liquid organic manures mainly bio-digester liquid manure, Panchagavya and cow-urine. Irrespective of liquid organic manures, the nutrient uptake and fertility status of soil viz., N, P and K content and uptake, available nitrogen, phosphorus and potassium status were significantly higher with $7.5 \mathrm{t} \mathrm{FYM}+\mathrm{RDF}(100: 50: 25) \mathrm{N}, \mathrm{P}_{2} \mathrm{O}_{5}, \mathrm{~K}_{2} \mathrm{O} \mathrm{kg} \mathrm{ha}^{-1}+10 \mathrm{~kg} \mathrm{ZnSO}_{4}(\mathrm{RPP})$ and RDF alone as compared to nutrient substitution through organic manures. Similarly, organic carbon and micronutrients (viz., $\mathrm{Cu}, \mathrm{Zn}$, Mn and Fe content) were significantly higher with application of organic manurial treatments over RDF and RPP. Among the organic manurial treatment combinations GLM + EC + VC (top dressing at GGS) was significantly superior over basal applied vermicompost.
\end{abstract}

Key Words : Organic manures, Liquid organic manures, N, P and K content, N, P and K uptake, Available N, P and K status, Micronutrients, Organic carbon, RPP (Recommended package of practice), RDF (Recommended dose of fertilizer)

View Point Article : Waghmode, B.R., Sonawane, S.V. and Tajane, D.S. (2015). Evaluation of different sources of organics on fertility status of soil and nutrient uptake of sweet corn (Zea mays L. saccharata). Internat. J. agric. Sci., 11 (2) : 290-296.

Article History : Received : 08.12.2014; Revised : 22.05.2015; Accepted : 29.05.2015

\footnotetext{
* Author for correspondence (Present Address) : Department of Agronomy, K.K. Wagh College of Agriculture, NASIK (M.S.) INDIA ${ }^{1}$ K.K. Wagh College of Agriculture, NASIK (M.S.) INDIA
} 